\title{
DIRECT SELLING ETHICS: AN EXPLORATORY INVESTIGATION ON TURKISH DIRECT SELLERS*
}

\author{
BAHTIŞEN KAVAK** \\ Hacettepe University
}

\author{
SANEM ALKİBAY*** \\ Gazi University
}

\author{
MAHMUT ARSLAN**** \\ Hacettepe University
}

\begin{abstract}
This study investigates the ethical evaluations of Turkish direct sellers of ethical dilemmas involving consumer complaints. In addition, the effects of market competition as well as some individual factors such as demographics, ethical ideology, locus of control, and Machiavellianism on direct sellers' judgments are also examined. The results suggest that the level of perceived market competition, formal education, external locus of control, relativism, and Machiavellianism explain the ethical evaluations of Turkish direct sellers.
\end{abstract}

Key Words: direct selling ethics, consumer complaints, Turkey.

\section{DOĞRUDAN SATIŞ ETIĞİ: TÜRKIYYE'DEKI DOĞRUDAN SATIS ELEMANLARI ÜZERINDE KEŞIFFSEL BIR ARAŞTIRMA}

\section{$\ddot{O Z E T}$}

Bu çalışmanın amacı, Türkiye'deki doğrudan satış elemanlarının, tüketici şikayetlerinden oluşturulmuş ahlaki olaylar hakkındaki değerlendirmelerini araştırmaktır. Bunun yanı sıra, piyasadaki rekabet ile satışcıların demografik özellikleri, ahlaki ideolojileri, denetim odaklılık ve Machevelizm düzeyleri gibi kişisel bir takım özelliklerinin de ahlaki değerlendirmeler üzerindeki etkisi incelenmiştir. Elde edilen sonuçlara göre, piyasadaki rekabetin algllanan düzeyi, eğitim düzeyi, dışsal denetim odaklılık, görecelilik ve Makyevelizm doğrudan satışçıların ahlaki değerlendirmelerini etkilemektedir.

Anahtar Kelimeler: doğrudan satış etiği, tüketici şikayetleri, Türkiye

This study explores the ethical evaluations of direct sellers who sell in a non-store environment, primarily at home, and hence, are different from typical salespeople who sell at stores.

* We would like to thank the reviewers for their insightful comments.

** Bahtışen Kavak is an Associate Professor in the Department of Management at Hacettepe University, 06532, Beytepe, Ankara, Turkey. E-mail: bahtisenkavak@yahoo.com

*** Sanem Alkibay is a Professor in the Department of Business Education at Gazi University, 06830, Gölbaş1, Ankara, Turkey. E-mail: salkibay@ gazi.edu.tr

**** Mahmut Arslan is an Associate Professor in the Department of Management at Hacettepe University, 06532, Beytepe, Ankara, Turkey. E-mail: marslan@hacettepe.edu.tr 
Ethics is about what to do, what would be good or bad, right or wrong, wise or unwise to do (Post et al., 2005). The philosophical study of morality has been concerned especially with finding a set of moral principles or rules that would hold appropriate for all people (Narvesson, 1998). Ethics can also be defined as the study of human action and its moral adequacy. Business ethics, then, is the study of business action -individual or corporate- with special attention to its moral adequacy (Goodpaster, 1998). Business people at different hierarchical levels in organizations of different sizes and degrees of complexity confront ethical issues (Goodpaster, 1998). In explaining ethical responsibilities business ethics generally uses the concept of stakeholders. Stakeholders are individuals or group that can affect or can be affected by an organization's activities, policies, and decisions (Post et al., 2005).

Stakeholder theory includes a set of propositions that suggest managers of business corporations have obligations to some group of stakeholders. "Stakeholder" is an ironic twist of stockholder to signal that firms may well have broader obligations than the traditional economic theory has assumed. The main stakeholder groups are owners, creditors, customers, employees, unions, competitors, suppliers, government, political groups, activist groups, customer advocate groups, and trade associations (Freeman, 1999). Customers are the primary stakeholders; that is, their existence is vital for the survival of a business organization.

The relationship between customers and organizations is generally studied in the marketing field, and the ethical aspects of this relationship are investigated in the marketing ethics field. "Marketing ethics" is the study of how moral standards are applied to marketing decisions, behaviors, and institutions (Tsalikis and Fritzche, 1989). Among other topics such as pricing, promotion activities, and sales promotion, personal selling has appeared as the major research area in marketing ethics. This is mainly because a personal seller is like a bridge between the firm and its customers, and it has been revealed that (McClaren, 2000) salespeople seem to be most prone to act unethically when one or more of the following situations exist:

- Competition is intense

- Crises times in the economy

- Compensation is based exclusively on commission

- Questionable dealings are common industry practice

- Sales training is non-existing or abbreviated

- The individual has limited selling experience

- Lack of formal organizational control with an existing code of conducts

Sales managers operate in a position above the sales representatives and are charged with administering the territories of salespersons and competitors as well as regular communication with their salespersons about company policies and personal ethical concerns. Personal ethical concern is more important for a direct seller than for other salespersons. Direct selling is a non-store retailing, and there is a lack of formal organizational control over the relationship between direct sellers and customers. As Frederick et al. (1992) specify, consumers should be protected against direct sellers' unethical activities that violate consumer rights, such as:

- The right to safety: To be protected against the marketing of goods that are hazardous to health or life;

- The right to be informed: To be protected against fraudulent, deceitful, or grossly misleading information, advertising, labeling, or other practices, and to be given the facts to make an informed choice; 
- The right to choose: To be assured, wherever possible, access to a variety of goods and services at competitive prices;

- The right to be heard: To be assured that consumer interests will receive full and sympathetic consideration in the formulation of government policy and fair treatment in its administrative tribunals.

Based on the above discussion, it can be proposed that the ethical evaluations of direct sellers might be different from those of salespersons in personal selling. In a similar manner, Chonko et al. (2002) suggested that the ethics of the direct selling industry should be discussed.

The ethical evaluations of salespersons in personal selling has been examined in the literature (Schneider and Johnson, 1992; Verbeke et al., 1996); however, there is a lack of studies that focus on the ethical evaluations of direct sellers. This lack is the basic reason underlying the present study, which aims to investigate the ethical evaluations of Turkish direct sellers of ethical dilemmas that involve consumer complaints. Another reason for conducting this study is the importance of the direct selling industry in Turkey. This importance comes from the magnitude of volume as well as recent studies about establishing the Turkish Ethical Codes of Direct Selling Ethics in accordance with the FEDSA standards of the European Union. Both are explained in the sections below. Before these sections, the differences between direct selling and direct marketing, which are often used interchangeably, are discussed. Hence, the following sections are related to the difference of direct selling and personal selling, and the direct selling industry in Turkey.

\section{Direct Selling versus Direct Marketing}

Direct selling is often thought to be the same thing as direct marketing. Direct marketing is the use of consumer-direct channels to reach and deliver goods and services to customers without using marketing middlemen. These channels include direct mail, catalogs, tele- marketing, interactive TV, kiosks, Web sites, and mobile devices (Kotler, 2003: 620). Direct selling is, on the other hand, a type of consumer goods marketing and a distribution method involving face-to-face contact between an independent salesperson and a buyer away from a fixed business location, primarily at home (Wotruba, 1992; Kotler, 2003: 536). Thus, even though both are typical examples of non-store retailing, the middleman is the vital actor in direct selling. Tupperware and Avon are some well-known examples of organizations in the direct selling industry.

The importance of direct selling has been growing, and there are many opportunities for direct selling both from the economic and the human response points of view (Millar, 1995). Direct selling provides many goods and services that are not available through traditional retail outlets, and that are new for the market as well. In addition, many people are employed in the direct selling industries of many European countries. Moreover, direct selling plays a key role in the development of entrepreneurship. This is because direct selling allows individuals to start their own businesses with little or no previous sales experience. Another function of direct selling is that it is still an important distribution channel for a number of goods and services and it has a very loyal group of participants on both the supply and demand sides in many countries around the world (Rosenbloom, 1995).

In spite of the importance of the direct selling industry, there are many fraudulent trading schemes against which consumers and sellers need to be protected. The World Federation of Direct Selling 
Association and the Federation of European Direct Selling Association, for instance, set their own codes of conduct to protect buyers and sellers in an attempt to promote direct selling as an ethical channel of distribution (Euromonitor, 2000).

\section{Differences of Direct Selling Ethical Conduct from the Others in Marketing}

The discussion in the previous section provides some cues that help explain why ethical codes of conduct in direct selling may be evaluated differently from those in traditional marketing. There are a number of reasons that make direct selling ethics a different topic (Chonko et al., 2002). The first reason is that salespeople in direct selling organizations are considered to be independent contractors rather than employees of the organization (Chonko et al., 2002: 87). Unlike other salespersons working in a company, direct sellers are typically autonomous due to the lower level of control or impact of the company. Therefore, the willingness of a direct seller to engage in an unethical or ethical action is influenced by the ethical judgments of buyers and sellers. This argument is supported by Robertson (2003), who found that direct and indirect situational factors contribute to unethical actions in the sales context.

The position in the channel of distribution may influence the ethical judgments of buyers and sellers (Dubinsky and Levy, 1985). Direct salespeople are guests in the homes of their customers. Due to the absence of external managerial control of the seller, the communication at home may be affected by the sellers' personal moral values (Buchanan, 1996). For this reason, salespersons' personality characteristics and values such as ethical ideology (Barnett et al., 1998; Malhotra et al., 1998; Rawwas et al., 1998; Chan and Leung, 2006), locus of control (Trevino, 1986; Vitell, 1991; Whalen et al., 1991), and Machiavellianism (Hunt and Chonko, 1984; Rayburn and Rayburn, 1996) might be important contributors to the unethical behaviors of direct sellers.

According to Wotruba and Pribova (1995), consumers perceive direct sellers as pushy, invading their privacy, and unreliable. Therefore, customers' perceived risk of buying products through direct sales at home might be higher compared to other modes of shopping (Rosenbloom, 1995). This is because there is a negative impression held by a significant portion of potential customers toward direct selling in general (Baranowe and McNabb, 1992).

The economic benefit/loss of the activity might affect the ethical sensitivity of both buyers and sellers. The primary objective of the buyer and the seller is to receive as high an individual economic benefit as possible; therefore, if a purchasing activity provides less benefit to him or her, the customer and/or the seller can behave unethically in order to gain more benefit. Evidence for this argument is provided by the study of Nebenzahl et al. (2001). This study found that Turkish and Israeli customers ignore an unethical event if their economic benefit is low and economic loss is high. This argument is also supported by Schneider and Johnson (1992). Hence, it can be concluded that the higher the economic benefit of the consumer, the higher the possibility of ignoring the unethical behavior of the direct seller.

In addition to economic benefit, some other antecedents of the ethical behavior related to the personal characteristics of individuals such as ethical ideology (Malhotra et al., 1998), locus of control (Chan and Leung 2006), and Machiavellianism (Rayburn and Rayburn, 1996), may moderate or regulate the unethical involvement for both the buyer and the seller in a direct selling situation. The effects of these personal characteristics on ethical behavior are addressed in the following sections. 


\section{Ethical Ideology}

Forsyth (1980) classifies people into two broad and four subcategories according to their ethical ideology: Relativists (situationist, subjectivist), and idealists (exceptionists, absolutists). Situationists reject moral rules and analyze each moral act in each situation. Subjectivists evaluate each ethical act/ dilemma according to their personal values and perspectives rather than universal moral principles. In other words, ethical relativism states there is no definitive right or wrong. Thus, behavior cannot be judged to be absolutely right/ethical or wrong/unethical; rather, ethical courses of action are determined by the individual.

According to idealism, on the other hand, there are absolute "rights and wrongs" in all situations and cultures. Exceptionists are utilitarians who judge in terms of moral absolutes but accept some exceptions to these standards. Exceptionists could be called lesser idealists. However, both high idealists and absolutists will assume that if universal moral rules are followed, the best possible outcome will be achieved. An empirical study (Barnett et al., 1998) supported the significant influence of personal moral philosophy on the ethical decision making of marketing professionals, and revealed that "marketers' ethical judgments about the situations differed based on their ethical ideology, with absolutists rating the actions as most unethical" (p. 715). In addition, the relationship between ethical ideology and ethical behavior is also supported for marketing researchers (Malhotra et al., 1998), final consumers (Rawwas et al., 1998), and accounting students (Chan and Leung 2006). However, no studies have been done on direct sellers. Therefore, the present study tries to evaluate the effect of ethical ideology on direct sellers' ethical behavior.

\section{Machiavellianism}

Machiavellian orientation is an individual's general strategy for dealing with other people and the degree to which individuals feel they can manipulate others in interpersonal situations (Rayburn and Rayburn, 1996). A Machiavellianist individual is one who has an immoral reputation for dealing with others to accomplish his or her own objectives, and for manipulating others for his or her own purpose (Christie and Geis, 1970: 1).

As for marketing and Machiavellianism, "Marketing has its share of machiavellians - no more no less" (Hunt and Chonko, 1984: 39). In their study, Hunt and Chonko (1984) did not find support for the relationship of Machiavellianism and success in marketing; however, they found that "people who are high in Machiavellianism seem to be less satisfied with their marketing careers then those who are low in Machiavellianism" (p. 40).

Moreover, Machiavellianism was defined as an explanatory variable for ethical evaluations of salespeople (Singhapakdi and Vitell, 1991, 1992), and the sales performance of stockbrokers (Aziz et al., 2002).

Depending on the above findings, the present study aims to investigate whether direct sellers who are high in Machiavellianism ignore the unethicalness of their own behaviors.

\section{Locus of Control}

Locus of control refers to an individual's externality and internality. The external individual perceives that the event is contingent upon chance, fate, luck, and he is under the control of others; Locus internals, 
however, believes that reinforcements are primarily contingent on his own behavior or permanent characteristics (Rotter, 1966: 1). In other words, it concerns individuals' perceived ability to affect the events in social circumstances. An individual with an internal locus of control (i.e., internal individual) believes that personal power or effort is a basic determinant of the outcomes of social events; whereas, an individual with an external locus of control (i.e, external) believes that events in social life are not under his or her control (Trevino, 1986). A recent study from Chan and Leung (2006) supported that internal accounting students are more likely to show an ability to recognize ethical issues than those characterized as externals.

Few studies have examined the role of locus of control in marketing ethics. One study found that marketers with a high external locus of control tend to be lower in their deontological norms (Singhapakdi and Vitell, 1991). Another study (Cherry and Fraedrich, 2000) showed that internal sales managers show greater disapproval of unethical behavior. Whalen et al. (1991) investigated the differences of ethical evaluations of internal and external consumer. However, there has been no study about direct sellers' locus of control and their ethical evaluations. Hence, the present study investigates this correlation.

\section{Direct Selling Industry in Turkey}

In Turkey, the importance of the direct selling industry is growing with 600,000 direct sellers associated with the Direct Selling Association, which created sales of 800 million New Turkish Liras in 2005 (Ekonomist, 2005: 2). These figures are quite comparable with the employment level of 13,300,000 direct sellers and the sales of $\$ 29.5$ billion in the US (Ekonomist, 2005: 6). In August 1994, the Direct Selling Association of Turkey issued the first publication of the Ethical Codes of Conduct among firms, direct sellers, and customers. The goals of the Direct Selling Association of Turkey are: (1) to develop the direct selling industry in Turkey, (2) to develop the work ethics properly in direct selling, and (3) to improve the image of direct selling firms and direct salespeople. Nowadays, this association, as a member of the Federation of European Direct Selling Association (FEDSA), is working to modify the codes of conduct in accordance with the consumers' ethical concerns.

In order to establish the work ethics standards of business efficiently in Turkish direct selling in accordance with those of the FEDSA standards of the European Union, and to achieve the other goals specified above, it is crucial to understand what the Turkish direct sellers' ethical judgments are. The present study, therefore, examines the ethical evaluations of the direct sellers of certain ethically questionable actions, which were based on consumer complaints.

\section{Recent Research on Direct Selling Ethics}

According to the ethics literature review of Loe et al. (2000) "research on the ethics of personal selling and sales management has continued to increase in volume and importance" (p. 285); however, very few studies have been conducted on direct sellers' ethical evaluations. One of these studies, for example, belongs to Wotruba et al., (2001), in which the impact of ethics code familiarity on manager behavior in the direct selling industry of the USA was investigated. Another one (Chonko et al., 2002) found that direct selling executives perceive opportunities for unethical behavior in direct selling, and served as a benchmark for subsequent research on ethics in the direct selling industry. 
Furthermore, there is a lack of studies that examine the relationship between the ethical/ unethical intentions of direct sellers and their individual characteristics such as ethical ideology, Machiavellianism, and locus of control. Even though many studies have investigated the impact of individual characteristics on ethical intentions, they mainly have concentrated on the ethics of salespersons who work in companies rather than those of direct sellers. Studies on Machiavellianism mostly have focused on the relationship between the Machiavellianistic tendencies of salespeople and their perceptions of ethical problems (Singhapakdi and Vitell 1991, 1992), and the sales performance of stockbrokers (Aziz et al., 2002). Locus of control as a personality characteristic was investigated by Srivastava and Sager (1999) as a determinant of the Problem-Focused Coping (PFC) style, and by Cherry and Fraedrich (2000) as an indicator of sales managers' decision-making process. Studies on ethical ideology also have focused on salespeople in companies rather than direct sellers, examining the effects of the idealism and relativism levels of marketing professionals (Barnett et al,. 1998), the ethical judgments of salespeople (Boyle 2000), and the relationship between the ethical ideologies of sales managers, and their hiring intentions and ethical evaluations (Sivadas et al., 2002). Finally, a study (Ergeneli and Arıkan, 2002) conducted in Turkey investigated the gender differences in the ethical perceptions of salespeople, not of direct sellers.

\section{Research Questions}

The review of the literature presented above shows that ethical behaviors of direct sellers is an underestimated area in the marketing ethics field. Thus, the present study intends to contribute to the related area by investigating the following research questions:

1. What level of ethical/unethical intentions do Turkish direct sellers have?

2. Do individual variables such as demographic characteristics, ethical ideology, locus of control, and Machiavellianism have influences on the ethical judgments of Turkish direct sellers?

\section{RESEARCH METHODOLOGY}

\section{Questionnaire Development and Measurement}

In order to examine the research questions of this study, data were collected using a questionnaire. The first part of the questionnaire included the Locus of Control Index developed by Rotter conducted by Whalen et al. (1991). This scale was employed by Nebenzahl et al. (2001) in a study on Israeli and Turkish students and had Chronbach's alphas of 0.74 for the Israeli sample and 0.65 for the Turkish sample; thus, this provides an opportunity to compare the findings of that study with the present one. The scale consists of 14 statements of which 12 are related to external locus of control (i.e., externality) and two are related to internal locus of control (i.e., internality) (See Appendix 1). Respondents were asked to indicate their disagreement and agreement with those statements using a five-point Likert scale. The two statements representing internality were reverse-coded so that the whole scale measured the degree of externality of the individual. The reliability (i.e., coefficient alpha) of the Locus of Control Index in the present study was $71 \%$.

The second part of the questionnaire covers the Ethics Position Questionnaire developed by Forsyth (1980) to measures ethical ideology. This measure includes two scales of 10 statements each. The first 10 statements are designed to measure Idealism, and the remaining 10 statements are designed 
to measure Relativism (See Appendix 2). The respondents were asked to indicate their agreement or disagreement with these statements using a five-point Likert scale. According to the mean scores of one's response to the idealism and relativism scales, respondents who have high scores on both scales are "situationists" and those who are high on the idealism scale but low on relativism are classified as "absolutists." Respondents low on idealism but high on relativism are "subjectivists" and those low on both scales are considered "exceptionists." Chronbach's coefficient alphas were 0.77 for the Idealism scale and 0.80 for the Relativism scale. These alpha values are comparable with those of previous studies. For example, alpha values for idealism and relativism were 0.62 and 0.64 , relatively, in the study of Rawwas et al. (1996) on the ethical beliefs of Austrian consumers, and 0.85 and 0.83 in the study of Vitell et al. (1991) of elderly consumers. A more recent study (Rawwas et al., 1998) investigating the ethical beliefs and the ethical ideology of Irish and Lebanese consumers had Chronbach's alphas of 0.85 and 0.84 for idealism, and 0.81 and 0.79 for relativism.

The third part of the questionnaire consisted of 12 short scenarios that included ethical situations representing Turkish consumers' written complaints regarding direct selling activities. These situations were obtained from a list of 14,977 written customer complaints from all around Turkey related to direct selling that were collected (but not published) by the Ministry of Industry and Trade of the Turkish Republic between 1999 and 2001. The consumer complaints regarding direct sellers were classified by the authors of the present study into the following 12 issues, ordered by frequency of mention: (1) Over pricing, (2) Not giving the withdrawal certificate, (3) Not accepting the customer's return of product, (4) False promises (e.g., gift) used to close sale, (5) Intentionally lying about the expiration date of withdrawal certificate, (6) Not giving the sales receipt, (7) Using strong pressure tactics to close a sale, (8) Not filling out the contract in accordance with the direct selling rules, (9) Not giving the guarantee certificate, (10) Not delivering on time, (11) Delivering a different product, and (12) Not accepting the faulty product to prevent losses.

Consumer complaints should be emphasized because of the continuing process of EC full membership of Turkey. Consumer protection should be improved by better response to consumer complaints (Kaynak et al., 1992). In order to manage consumer complaints and concerns, especially in direct selling environment, direct sellers who are the major actors should accept that those issues are critical.

Therefore, direct sellers were asked to indicate whether they agree that these activities were unethical on a five-point Likert scale ranging from 1 (highly disagree) to 5 (highly agree), so that a high score would indicate high ethicalness. Internal reliability of these 12 items was 0.75 . Thus, these ethical statements appeared to be adequate for further analysis.

The fourth part of the questionnaire included the Mach IV scale (See Appendix 3) adopted from Christie and Geis (1970) with a Chronbach alpha of 0.79, and translated into Turkish and employed by Kavak (2001) with a Chronbach alpha of 0.58 . The reliability of the scale in the present study was 0.72 . This is in the satisfactory range for further analysis compared to 0.67 in the study of Verbeke et al. (1996). For these 20 statements, a five-point Likert scale was used.

In the last part of the questionnaire several demographic variables were included to see if there might be any differences in ethical judgments based on these variables. The demographics included gender, age, marital status, education level, job experience, existence of social security, major source of income, and perceived intensity of market competition. 


\section{Sample and Data Collection Procedure}

In the sampling stage the basic problem was the magnitude of the main population. As mentioned above, the number of direct sellers that are members of the Turkish Direct Sellers Association is 600,000 . However, this is not an accurate number since the direct sellers to be included in the list were not determined in an appropriate way, thereby making it impossible to know the actual population size. Therefore, the number of respondents for each part of the questionnaire was computed using the formula, $\mathrm{n}=\mathrm{t}^{2} \mathrm{x} \sigma^{2} / \alpha^{2}$ (Hair et al. 2000, p. 339), where $\mathrm{t}$ is the standardized $\mathrm{t}$-value associated with the level of confidence of $95 \%$ (1.96), $\sigma$ is the estimate of the population standard deviation based on some type of prior information (0.15), and $\alpha$ is the acceptable tolerance level of error (0.5). The minimum sample size for each part of the questionnaire was calculated to be 36, thus a total of 144 respondents. In order to guarantee at least 144 usable questionnaires, 500 questionnaires were distributed. These questionnaires were given to the head of the Turkish Direct Sellers Association, which mailed them to the sales managers of six firms in the cosmetics and kitchen utensils sectors that are members of the Association. The authors explained the purpose and the contents of the questionnaire to the sales managers who distributed the questionnaires to direct sellers. A total of 210 usable questionnaires were returned. Additionally, as a result of callback and a second mailing 190 usable questionnaires were returned. Therefore, a total of 400 questionnaires were included in the analysis. Of the 400 direct sellers, $91 \%$ were female and $9 \%$ were male. Even though the sample of this study consists of $91 \%$ females, this does not create a major burden since the questionnaires were sent to six companies in the cosmetics and kitchen utensils sectors, which are generally dominated by female sellers. Hence, the nature of the examined sectors necessitates the employment of female salespersons. The percentage distribution for age was $23.3 \%, 58.0 \%, 18.8 \%$ for the range of $17-30,31-45$, and $45+$, respectively. Other demographic information is presented in Table 1.

\section{Methods of Analysis}

Two types of analyses were conducted in this study. First, the overall evaluations of the direct salespeople were examined, and the relationships between ethical evaluations and demographic variables (gender, age, marital status, education level, job experience, existence of social security, major source of income), and perceived market competition level were tested using one-way ANOVA. Then, multiple regression analysis was conducted to examine the relationships between the ethical evaluations of the salespeople and locus of control, ethical ideology, and Machiavellianism levels.

\section{Findings}

Descriptive statistics for the Turkish direct sellers' evaluations of the unethical activities in direct selling circumstances are presented in Table 2. As can be seen from the table, first of all, the overall mean of the evaluations of unethical activities was 2.6155 (with a standard deviation of .7531), and was under the middle point of three, suggesting a lower degree of ethicalness. Secondly, the Turkish direct sellers divide the presented ethically questionable actions into three categories: The most unethical actions, less unethical actions, and neither ethical nor unethical actions. According to the Turkish direct sellers, not giving a guarantee certificate, not delivering on time, delivering a different product, not accepting the faulty product to prevent losses, false promises used to close sale, intentionally lying about the expiration date of withdrawal certificate, and not giving the sales receipt are the most 
unethical actions in direct selling. On the other hand, not filling out the contract in accordance with the direct selling rules, and using high pressure tactics to close sale are considered less unethical. The direct sellers evaluated the actions of not giving withdrawal certificate, not accepting the customer's return of product, and overpricing as being neither ethical nor unethical. In other words, they do not have a certain opinion about whether these are unethical activities, since the mean values were highly close to the mid-point of three.

Table I

Demographic Characteristics of the Respondents

\begin{tabular}{|c|c|c|c|}
\hline Characteristics & $\%$ & Characteristics & $\%$ \\
\hline Age & & Job experience & \\
\hline $17-30$ & 23.3 & $0-6$ month & 24.0 \\
\hline $31-45$ & 58.0 & 7-11 month & 13.3 \\
\hline \multirow[t]{3}{*}{$45+$} & 18.8 & $1-2$ years & 20.3 \\
\hline & & 3 years + & 42.4 \\
\hline & & No response & 0.3 \\
\hline Gender & & Social security & \\
\hline Female & 91.0 & Yes & 58.3 \\
\hline Male & 9.0 & No & 41.8 \\
\hline Marital status & & Major source of income & \\
\hline Single & 25.0 & Sales commission & 74.3 \\
\hline \multirow[t]{2}{*}{ Married } & 75.0 & Salary & 6.8 \\
\hline & & Commission + Salary & 19.0 \\
\hline Education level & & Perceived Intensity of market competition & \\
\hline Primary & 22.0 & Highly competitive & 47.0 \\
\hline High School & 51.2 & Moderately competitive & 38.5 \\
\hline \multirow[t]{2}{*}{ University } & 27.8 & No competition & 14.2 \\
\hline & & No response & 0.3 \\
\hline
\end{tabular}

One-way ANOVA was used to determine whether direct sellers differed in their ethical evaluations with respect to individual factors of gender, age, marital status, education level, job experience, existence of social security, and major source of income, and factors related to the industry, e.g., the intensity of market competition. 
Table 2

Descriptive Statistics for the Unethical Activities and

Individual Attributes of the Respondents

\begin{tabular}{|c|c|c|c|}
\hline Unethical Activities and Individual Attributes & $N$ & Mean & Std. Deviation \\
\hline 1. Over pricing & 400 & 2.9700 & 1.6235 \\
\hline 2. Not giving withdrawal certificate & 400 & 3.0600 & 1.7216 \\
\hline 3. Not accepting the customer's return of product & 400 & 3.5125 & 1.6375 \\
\hline 4. False promises (e.g., gift) used to close sale & 400 & 2.2300 & 1.6489 \\
\hline $\begin{array}{l}\text { 5. Intentionally lying about the expiration } \\
\text { date of withdrawal certificate }\end{array}$ & 400 & 2.4475 & 1.6835 \\
\hline 6. Not giving the sales receipt & 400 & 2.2400 & 1.6399 \\
\hline 7. Using high pressure tactics to close sale & 400 & 4.0900 & 1.1939 \\
\hline $\begin{array}{l}\text { 8. Not filling out the contract in accordance } \\
\text { with the direct selling rules }\end{array}$ & 400 & 4.1125 & 1.4578 \\
\hline 9. Not giving the guarantee certificate & 400 & 1.7175 & 1.3331 \\
\hline 10. Not delivering on time & 400 & 1.9425 & 1.3430 \\
\hline 11. Delivering different product & 400 & 1.7200 & 1.2945 \\
\hline 12. Not accepting the faulty product to prevent losses & 399 & 1.3133 & 0.9820 \\
\hline Overall & 399 & 2.6155 & 0.7531 \\
\hline Locus of Control & 400 & 2.6098 & 0.6212 \\
\hline Idealism & 400 & 4.5603 & 0.5180 \\
\hline Relativism & 400 & 3.6807 & 0.8543 \\
\hline Machiavellianism & 399 & 3.3030 & 0.5172 \\
\hline
\end{tabular}

Note: Higher mean values for the activities refer to higher degrees of ethicalness. 
Before that, whether the results can be influenced by an unequal sample distribution such as percentage of gender and marital status should be tested (see Table 1). For this purpose the coefficients of variations of those distributions are computed. The results showed that the coefficients are $0.22,0.37,0.30,0.28$ for female, male, single and married groups, and standard errors are 1.45, 1.35, 0.85 and

Table 3

Mean Values of the Unethical Activities with Respect to Individual Factors

\begin{tabular}{|c|c|c|c|c|}
\hline Individual / Industrial Factors & $\mathrm{N}$ & Mean & $\mathrm{F}$ & Significance $(\mathrm{p})$ \\
\hline \multicolumn{5}{|l|}{ Gender } \\
\hline Female & 36 & 2.6114 & 1.974 & 0.161 \\
\hline Male & 363 & 2.3542 & & \\
\hline \multicolumn{5}{|l|}{ Age } \\
\hline $17-30$ & 92 & 2.6766 & 2.578 & 0.077 \\
\hline $31-45$ & 232 & 2.5463 & & \\
\hline $45+$ & 75 & 2.7544 & & \\
\hline \multicolumn{5}{|l|}{ Marital status } \\
\hline Single & 100 & 2.7275 & 2.966 & 0.086 \\
\hline Married & 299 & 2.5780 & & \\
\hline \multicolumn{5}{|l|}{ Education level } \\
\hline Primary & 84 & 2.3288 & 14.117 & 0.000 \\
\hline High School & 205 & 2.6646 & & \\
\hline University & 110 & 2.8710 & & \\
\hline \multicolumn{5}{|l|}{ Job experience } \\
\hline 0-6 month & 95 & 2.4803 & 3.809 & 0.010 \\
\hline 7-11 month & 53 & 2.6226 & & \\
\hline $1-2$ years & 81 & 2.6698 & & \\
\hline 3 years + & 169 & 2.7930 & & \\
\hline \multicolumn{5}{|l|}{ Social security } \\
\hline Yes & 233 & 2.6184 & 0.008 & 0.928 \\
\hline No & 166 & 2.6114 & & \\
\hline \multicolumn{5}{|l|}{ Major source of income } \\
\hline Compensation & 297 & 2.6201 & 0.859 & 0.425 \\
\hline Salary & 27 & 2.4414 & & \\
\hline Compensation + Salary & 75 & 2.6600 & & \\
\hline \multicolumn{5}{|l|}{$\begin{array}{l}\text { Perceived Intensity of market } \\
\text { competition }\end{array}$} \\
\hline Highly competitive & 188 & 2.8099 & 5.7772 & 0.003 \\
\hline Moderately competitive & 154 & 2.7008 & & \\
\hline No competition & 57 & 2.4867 & & \\
\hline
\end{tabular}


0.76 respectively. Since the coefficients are less than 0.50 and standard errors are less than two, it can be assumed that female and male sample distributions and single and married sample distribution are similar and comparable with each other even though the sample sizes are different.

In this frame the results of ANOVA are presented in Table 3. The findings indicate that the mean scores of the salespeople differ significantly at $95 \%$ confidence level only with respect to education level $(\mathrm{F}=14.117, \mathrm{p}=.000)$, the length of job experience $(\mathrm{F}=3,809, \mathrm{p}=0.010)$, and intensity of market competition $(\mathrm{F}=5.777, \mathrm{p}=.003)$. As the education level of the respondent increases, the tendency for ethical evaluation also significantly increases. This finding supports the study conducted by Kavak (2001), in which formal education was found to be an explanatory variable of ethical/unethical behaviors. Ethical evaluations also differed depending on the length of the direct seller's work experience. Direct sellers with more work experience had higher levels of ethical involvement in the customer-seller relationship. Moreover, the perceived level of competition in the market had a significant role in the ethical evaluations of Turkish direct sellers, suggesting that salespeople in highly competitive markets have higher ethical tendencies than those in less competitive markets. This might be due to the overall regulatory power of competition on markets, in other words, external control on salespeople. This finding supports the study of Schneider and Johnson (1992), which asserts that increased levels of competition led to higher levels of ethics.

In order to examine the effects of individual attributes of locus of control, ethical ideology, and Machiavellianism on direct sellers' ethical evaluations multiple regression analysis was conducted. The findings of this analysis are presented in Table 4.

It should be noted here that when checking for the appropriateness of the data for the multiple regression analysis, multicollinearity was assessed using the Variance Inflation Factor (VIF). As shown in Table 4, the VIFs ranged from 1.131 to 1.190 , well below the cut-off of 10 recommended by Hanke et al. (2001). This finding suggests that collinearity was not a likely threat to the conclusions drawn from the parameter estimates of the regression analysis. Thus, it was possible to go on with the analysis. As can be seen from Table 4, direct sellers' unethical judgments were significantly explained by their externality $(b=0.254, p=0.000)$, relativism $(b=0.117, p=0.003)$, and Machiavellianism $(b=$ $0.612, \mathrm{p}=0.000$ ). These results suggest that external, relativist, and Machiavellist sellers have higher tendency towards unethical activities. On the other hand, Idealism was not an explanatory variable for unethical evaluations, even though the sign of the regression coefficient was in the expected direction as previous work suggests (Loe et al., 2000).

Table 4

Multiple Regression Analysis of the Unethical Activities in Direct Selling

\begin{tabular}{lrrrll}
\hline Variable & B & Beta & T & Significance & VIF \\
\hline Constant & 0.131 & & -0.396 & 0.693 & \\
Locus of Control & 0.254 & 0.209 & 4.680 & 0.000 & 1.150 \\
Idealism & -0.080 & -0.056 & -1.250 & 0.212 & 1.131 \\
Relativism & 0.117 & 0.131 & 2.960 & 0.003 & 1.133 \\
Machiavellianism & 0.612 & 0.420 & 9.229 & 0.000 & 1.190 \\
\hline
\end{tabular}

Dependent variable: Mean Score of Unethical Scenarios

Adjusted $\mathrm{R}^{2}=0.32$ 


\section{CONCLUSION AND IMPLICATIONS}

This study was conducted to examine the level of ethical evaluations of Turkish direct sellers of certain unethical activities and to investigate the effects of locus of control, ethical ideology, Machiavellianism, individual variables on the ethical evaluations of direct sellers.

The analysis showed that the level of ethical tendency of the respondents was under the middle point. This suggests that the ethical tendency of Turkish direct sellers is low. Another result showed that formal education affects the direct seller's ethical tendency in a positive way. Therefore, education level should be an important selection criterion when hiring direct sellers. Besides, it might be recommended to the current and potential direct selling firms to educate their direct sellers for business ethics.

In addition to formal education, some other individual indicators namely, externality, relativism, and Machiavellianism, are explanatory variables for direct sellers' unethical evaluations. Even though the idealism level of Turkish direct sellers is higher than their relativism level, idealism is not influential in explaining their unethical evaluations.

In sum, unethical trading activities are promoted by direct sellers who are external, relativist, and Machiavellist. So, firm managers of direct selling industry in Turkey should control the direct sellers. For this, customer feedbacks can be utilized.

The low level of ethical tendencies of direct sellers can also be improved by the growth of market competition. This is because, according to the results of the present study, the ethical tendency of direct sellers is significantly higher with higher levels of perceived competition. The reason underlying the significant effect of competition may be due to the external regulatory power of competitors. Therefore, competition in the direct selling industry must be supported and developed. For this purpose, first, new firms might be encouraged to enter the Turkish Direct Selling Market. Second, direct sellers, who are the major actors in direct selling industry, should be trained in competition. Thus, a better functioning of the marketplace will be improved in order to eliminate unethical activities.

Another result of this study reveals that direct sellers classified the unethical activities into three categories as follows:

\section{1) Unethical actions;}

- Not giving guarantee certificate,

- Not delivering on time,

- Delivering a different product,

- Not accepting the faulty product to prevent losses,

- False promises used to close sale,

- Intentionally lying about the expiration date of withdrawal certificate, and not giving the sales receipt.

\section{2) Less unethical actions;}

- Not filling out the contract in accordance with the direct selling rules,

- Using high pressure tactics to close sale. 
3) Neither ethical nor unethical actions;

- Overpricing,

- Not giving a withdrawal certificate,

- Not accepting the customer's return of product.

Even though actions specified as neither ethical nor unethical have a high frequency of mention in the list of Turkish consumer complaints, they were not perceived as totally unethical. Due to the FEDSA direct selling ethical codes, this type of ethical evaluation will lead to some problems in terms of consumer protection when Turkey joins EU as a full member. However, "withdrawal certificate" and "accepting the customer's return of product" are relatively new practices in Turkey. Thus, it is recommended that the Turkish Direct Sellers Association educate its direct seller members on these new practices. Furthermore, Turkish direct sellers need further ethical education regarding filling out contract in accordance with the rules and not using high pressure on customers.

Finally, it should be noted that the findings of this study might be specific to Turkey, which has a developing market economy. The factors that were shown to influence ethical evaluations in this study might not have significant roles in other countries. Studies using the same ethical activities in different countries with similar and/or different market structures should be conducted in order to obtain comparable results. It is suggested that additional cross-cultural investigations on direct selling ethics be conducted in the future.

\section{REFERENCES}

Aziz, A., May, K., and Crotts, J.C. (2002). "Relations of Machiavellian Behavior with Sales Performance of Stockbrokers," Psychological Reports, 90: 451-460.

Baranowe, Y.T. and McNabb, D.E. (1992). "Consumer Responses to Direct Selling: Love, Hate, Buy," Journal of Marketing Channels, (winter): 25-40.

Barnett, T., Bass, K., Brawn, G., and Hebert, F.J. (1998). "Ethical Ideology and the Ethical Judgments of Marketing Professionals," Journal of Business Ethics, 17: 715-723.

Boyle, B.A. (2000). "The Impact of Customer Characteristics and Moral Philosophies on Ethical Judgments of Salespeople," Journal of Business Ethics, 23: 249-267.

Buchanan, A. (1996). "Perfecting Imperfect Duties: Collective Action to Create Moral Obligation," Business Ethics Quarterly, 6: 27-42.

Chan, S.Y.S. and Leung, P. (2006) "The Effects of Accounting Students' Ethical Reasoning and Personal Factors on Their Ethical Sensitivity," Managerial Auditing Journal, 21(4): 436-457.

Cherry, J. and Fraedrich, J. (2000). “An Empirical Investigation of Locus of Control and the Structure of Moral Reasoning: Examining the Ethical Decision-Making Processes of Sales Managers," Journal of Personal Selling \& Sales Management, 20(3): 173-188.

Chonko, L.B., Wotruba, T.R., and Loe, T.W. (2002) "Direct Selling Ethics at the Top: An Industry Audit and Status Report,” Journal of Personal Selling \& Sales Management, 22(12): 87-95. 
Christie, R. and Geis, F.L. (1970). Studies in Machiavellianism. New York: Academic Press.

Dubinsky, A.J. and Levy, M. (1985). "Ethics in Retailing: Perceptions of Retail Salespeople," Journal of the Academy of Marketing Science, 13(1): 1-16.

Ekonomist. (2005). “Direct Selling Association,” Nisan (April).

Ergeneli, A. and Arıkan, S. (2002). "Gender Differences in Ethical Perceptions of Salespeople: An Empirical Examination in Turkey," Journal of Business Ethics, 40: 247-260.

Euromonitor. (2000). "Direct Selling: A Global Market Focus Report.”

Forsyth, D.R. (1980). “A Taxonomy of Ethical Ideologies," Journal of Personality and Social Psychology, 39(1): 175-184.

Frederick, W.C., Post, J.E., and Davis, K. (1992). Business and Society Corporate Strategy Public Policy and Ethics. New York: McGraw-Hill.

Freeman R. E. (1999). "Response: Divergent Stakeholder Theory,” Academy of Management Review, 24: 233-236.

Goodpaster, K.E. (1998). "Business Ethics and Stakeholder Analysis, the Corporation and Its Stakeholders," in M.B.E. Clarkson (ed.), Classic and Contemporary Reading: 102-123. Toronto: Toronto Press.

Hair, J.F., Bush, R.P., and Ortinau, D.J. (2000). Marketing Research: A Practical Approach for the New Millennium. McGraw-Hill International Ed.

Hanke, J.E., Wichern, D.W., and Reitsch, A.G. (2001). Business Forecasting, Seventh Edition. New Jersey: Prentice Hall.

Hunt, S.D. and Chonko, L.B. (1984). "Marketing and Machiavellianism," Journal of Marketing, 48: $30-42$.

Kaynak, E., Küçükemiroğlu, O., and Odabaşı, Y. (1992) "Consumer Complaint Handling in an Advanced Developing Economy: An Empirical Investigation," Journal of Business Ethics, 11: 813829.

Kavak, B. (2001). "An Investigation on the Relationship between Machiavellianism and Consumers' Ethical Judgments,” Journal of Home Economics, 7(8): 11-20.

Kotler, P. (2003). Marketing Management. New Jersey: Prentice Hall.

Loe, T.W., Ferrell, L., and Mansfield, P. (2000). "A Review of Empirical Studies Assessing Ethical Decision Making in Business," Journal of Business Ethics, 25: 185-204. 
Malhotra, N.K. and Miller, G.L. (1998). “An Integrated Model for Ethical Decisions in Marketing Research.” Journal of Business Ethics, 17: 263-280.

McClaren , N. (2000) "Ethics in Personal Selling and Sales Management: A Review of the Literature Focusing on Empirical Findings and Conceptual Foundations," Journal of Business Ethics, 27(3).

Millar, C. (1995). "Direct Selling and Consumers' Values in Central and Eastern Europe," in T.R. Wotruba (ed.), Direct Selling in Central \& Eastern Europe: An International Academic Symposium (Proceedings): 33-62. Prague: 26-29 March.

Narveson, J. (1998). “Wrongness, Wisdom and Wilderness,” Journal of Agricultural and Environmental Ethics, 11(1): 58-61.

Nebenzahl, I.D., Jaffe, E.D., and Kavak, B. (2001). “Consumers' Punishment and Rewarding Process via Purchasing Behavior," Teaching Business Ethics, 5(3): 283-305.

Post, J.E., Lawrence, A.T., and Weber; J. (2005). Business and Society: Stakeholders, Ethics, PublicPolicy, 11th. Edition. Irwin: McGraw-Hill.

Rayburn, J.M. and Rayburn, L.G. (1996). "Relationship between Machiavellianism and the Type A Personality and Ethical Orientation,” Journal of Business Ethics, 15:1209-1216.

Rawwas, Y.A.M. (1996). "Consumer Ethics: An Empirical Investigation of the Ethical Beliefs of Austrian Consumers,” Journal of Business Ethics, 15:1009-1019.

Rawwas, Y.A.M., Patzer, G.L., and Vitell, S.J. (1998). "A Cross-Cultural Investigation of the Ethical Values of Consumers: The Potential Effect of War and Civil Disruption," Journal of Business Ethics, 17: 435-448.

Rosenbloom, B. (1995). "Direct Selling As a Channel of Distribution," in T.R.Wotruba (ed.), Direct Selling in Central \& Eastern Europe: An International Academic Symposium (Proceedings): 129-142. Prague: 26-29 March.

Robertson, D.C. (2003). “A Typology of Situational Factors: Impact on Salesperson Decision -Making About Ethical Issues," Journal of Business Ethics, 46: 213-234.

Rotter, J.B. (1966). "Generalized Expectancies for Internal Versus External Control of Reinforcement," Psychological Monographs: General and Applied, 80(1), Whole No: 609: 1-28.

Schneider, K.C. and Johnson, J.C. (1992). "Professionalism and Ethical Standards Among Salespeople in a Deregulated Environment: A Case Study of the Trucking Industry," Journal of Personal Selling \& Sales Management, 12: 33-44.

Singhapakdi, A. and Vitell, S.J. (1991a). "Analyzing the Ethical Decision Making of Sales Professionals," Journal of Personal Selling \& Sales Management, 11(4):1-12. 
(1991b). "Selected Factors Influencing Marketers' Deontological Norms," Journal of the Academy of Marketing Science, 19(1)37-42.

----- (1992). "Marketing Ethics : Sales Professionals Versus Other Marketing Professionals," Journal of Personal Selling \& Sales Management, 12(2): 27-31.

Sivadas, E., Kleiser, S.B., Kellaris, J., and Dahlstrom, R. (2002). "Moral Philosophy, Ethical Evaluations, and Sales Manager Hiring Intentions," Journal of Personal Selling \& Sales Management, 23(1): 7-21.

Srivastava, R. and Sager, J.K. (1999). "Influence of Personal Characteristics on Salespeople's Coping Style," Journal of Personal Selling \& Sales Management, 14(2): 47-57.

Trevino, L.K. (1986). "Ethical Decision Making in Organisations: A Person Situation Interactionist Model," Academy of Management Review, 11(3): 601-617.

Tsalikis, J. and Fritzche, D.J. (1989). "Business Ethics: A Literature Review with a Focus on Marketing," Journal of Business Ethics, 8(9): 695-743.

Verbeke, W., Ouwerkerk, C., and Peelen, E. (1996)."Exploring the Contextual and Individual Factors on the Ethical Decision Making of Salespeople," Journal of Business Ethics, 15: 1175-1187.

Vitell, S.J., Lumpkin, J.R., and Rawwas, M.Y.A. (1991). "Consumer Ethics: An Investigation of the Ethical Beliefs of Elderly Consumers,” Journal of Business Ethics, 10: 365-375.

Whalen, J., Pitts, R.E., and Wong, J.K. (1991). "Exploring the Structure of Ethical Attributions as a Component of the Consumer Decision Model: The Vicarious Versus Personal Perspective," Journal of Business Ethics, 10: 285-293.

Wotruba, T.R. (1992). "Direct Selling in the Year 2000," The Future of U.S. Retailing: 187-211. New York: Quorum Books.

Wotruba, T.R., Chonko, L.B., and Loe, T.W. (2001). "The Impact of Ethics Code Familiarity on Manager Behavior," Journal of Business Ethics, 33: 59-69.

Wotruba, T.R. and Pribova, M. (1995). "Direct Selling in Central Europe: A Comparision With the U.S." in T.R.Wotruba (ed.), Direct Selling in Central \& Eastern Europe: An International Academic Symposium (Proceedings): 87-104. Prague: 26-29 March. 


\section{APPENDIX}

\section{Locus of Control Index}

- My life is chiefly controlled by powerful others.

- In order to have my plans work, I make sure that they fit in with the desires of people who have power over me.

- If important people were to decide they didn't like me, I probably wouldn't make many friends.

- I feel like what happens in my life is mostly determined by powerful others.

- Getting what I want requires pleasing those people above me.

- Many times I feel I have little influence over the things that happen to me.

- People like myself have very little chance of protecting our personal interests when they conflict with those of strong pressure groups.

- It's chiefly a matter of fate whether or not I have few friends or many friends.

- I sometimes feel that I don't have enough control over the direction my life is taking.

- It is not always wise for me to plan too far ahead because many things turn out to be a matter of good or bad fortune.

- My life is determined by my own actions.

- Most students don't realize the extent to which their grades are influenced by accidental happenings.

- I am usually able to protect my personal interests.

- Getting a good job depends mainly on being in the right place at the right time.

\section{The Ethics Position Questionnaire}

- A person should make certain that his/her actions never intentionally harm another even to a small degree.

- Risks to another should never be tolerated, irrespective of how small the risks might be.

- The existence of potential harm to others is always wrong, irrespective of the benefits to be gained.

- One should never psychologically or physically harm another person.

- One should not perform an action which might in any way threaten the dignity and welfare of another individual.

- If an action could harm an innocent other, then it should not be done.

- Deciding whether or not to perform an act by balancing the positive consequences of the act against the negative consequences of the act is immoral.

- The dignity and welfare of people should be the most important concern in any society.

- It is never necessary to sacrifice the welfare of others.

- Moral actions are those which closely match ideals of the most 'perfect' action.

- There are no ethical principles that are so important that they should be a part of any code of ethics.

- What is ethical varies from one situation and society to another.

- Moral standards should be seen as being individualistic; what one person considers to be moral may be judged to be immoral by another person.

- Different types of moralities cannot be compared as to 'rightness'.

- Questions of what is ethical for everyone can never be resolved since what is moral or immoral is up to the individual. 
- Moral standards are simply personal rules which indicate how a person should behave, and are not to be applied in making judgments of others.

- Ethical considerations in interpersonal relations are so complex that individuals should be allowed to formulate their own individual codes.

- Rigidly codifying an ethical position that prevents certain types of actions could stand in the way of better human relations and adjustment.

- No rule concerning lying can be formulated; whether a lie is permissible or not permissible totally depends upon the situation.

- Whether a lie is judged to be moral or immoral depends upon the circumstances surrounding the action.

\section{Mach IV Scale}

- Never tell anyone the real reason you did something unless it is useful to do so.

- The best way to handle people is to tell them what they want to hear.

- One should take action only when sure it is morally right.

- Most people are basically good and kind.

- It is safest to assume that all people have a vicious streak and it will come out when they are given a chance.

- Honesty is the best policy in all cases.

- There is no excuse for lying to someone else.

- Generally speaking, people won't work hard unless they're forced to do so.

- All in all, it is better to be humble and honest than to be important and dishonest.

- When you ask someone to do something for you, it is best to give the real reasons for wanting it rather than giving reasons which carry more weight.

- Most people who get ahead in the world lead clean, moral lives.

- Anyone who completely trusts anyone else is asking for trouble.

- The biggest difference between most criminals and other people is that the criminals are stupid enough to get caught.

- Most people are brave.

- It is wise to flatter important people.

- It is possible to be good in all respects.

- P.T. Barnum was wrong when he said that there's a sucker born every minute.

- It is hard to get ahead without cutting corners here and there.

- People suffering from incurable diseases should have the choice of being put painlessly to death.

- Most people forget more easily the death of their parents than the loss of their property. 